\title{
Non-arteritic anterior ischemic optic neuropathy - Case report
}

\author{
Bordas Monica*, Tabacaru Bogdana***, Stanca Tudor Horia*** \\ * "Prof. Dr. Agrippa Ionescu" Clinical Emergency Hospital, Bucharest, Romania \\ **“Carol Davila” University of Medicine and Pharmacy, Bucharest, Romania \\ Correspondence to: Horia Tudor Stanca, MD, PhD, \\ "Carol Davila" University of Medicine and Pharmacy, Bucharest, Romania, \\ 8 Eroii Sanitari Blvd., District 5, Code 050474, Bucharest, Romania, \\ Phone +40722 761 454, E-mail address: hstanca@yahoo.com
}

Accepted: August 19th, 2018

\begin{abstract}
We present a case of Non-Arteritic Anterior Ischemic Optic Neuropathy (NA-AION) with uncertain etiology but a good recovery with a total gain of central visual acuity.

Keywords: Papillary Edema, Optic Disc Edema, Non-Arteritic Ischemic Optic Neuropathy

(NA-AION), Visual Field, Optic Nerve Atrophy, Optic Nerve Inflammation
\end{abstract}

\section{Introduction}

Ischemic optic neuropathy is an acute ischemic disorder of the optic nerve.

It is the most common acute optic neuropathy in patients over 50 years old, with an estimated annual incidence in the United States of 2.3-10.2 per 100000 population [1,2].

Ischemic optic neuropathies are of two types: Posterior Ischemic Optic Neuropathy, caused by ischemia of the posterior segment of the optic nerve, vascularized by multiple vessels, and Anterior Ischemic Optic Neuropathy, caused by ischemia of the anterior part of the optic nerve, supplied by the short posterior ciliary artery circulation. Etiologically and pathogenetically, AION is of the following two types: arteritic AION (A-AION), which is due to giant cell arteritis (Horton disease), and nonarteritic AION (NA-AION), which is due to all other causes $[3,4]$.

NAION presents with loss of vision occurring over hours to days, often described as blurring, dimness, or cloudiness in the affected region of the visual field, most often inferiorly. NAION typically presents without pain, although some form of periocular discomfort is reported in $8-12 \%$ of affected individuals $[\mathbf{5 , 6}]$.

Visual acuity in patients with NA-AION varies considerably, from 20/ 20 (logMAR 0) to no perception of light; however, in general, the drop in acuity in patients with NA-AION is less than that experienced by patients with the arteritic form of AION, with over $50 \%$ of the patients having acuity better than 20/ 200 (logMAR 1) [7]. Color vision loss in NA-AION tends to parallel visual acuity loss, as opposed to that in optic neuritis, in which color loss is often disproportionately greater than visual acuity loss. Visual field defects in NA-AION may follow any pattern related to optic nerve damage, but altitudinal loss, usually inferior, occurs in the majority, ranging from 55 to $80 \%$ of the reported cases [7-9].

\section{Case report}

A 52-year-old Caucasian man was admitted in another ophthalmological service for sudden decrease of visual acuity in the left eye after a brief period of physical effort associated with an 
event with emotional impact. The eye examination was inconclusive and the patient presented the next day in our clinic. General symptoms were absent at admission.

The patient had no relevant family history or ophthalmological afflictions but he declared a history of anxiety, depression and increased arterial blood pressure.

At presentation, his best-corrected visual acuity was 20/20 (0 logMAR) for the right eye and 20/ 200 (1 logMAR) for the left eye with a small spherical hyperopic correction. The intraocular pressure by applanation tonometry was $17 \mathrm{mmHg}$ in the right eye and $12 \mathrm{mmHg}$ in the left eye.

The findings on external examination and slit-lamp examination of the anterior segment were within normal limits aside from a relative afferent pupillary defect in the left eye.

The fundus of each eye was examined after pharmaceutical mydriasis with $0.5 \%$ tropicamide and $10 \%$ phenylephrine hydrochloride ophthalmic solutions (Fig. 1,2). The optic nerve disc in the left eye was imprecisely delimited, had a swollen appearance and the cupping was absent, this aspect being highly suggestive for papillary edema. The retinal arteries were narrowed, the veins were turgescent, and the vessels had a concentric arrangement. The macula appeared within normal limits. The ophthalmoscopy examination of the right eye showed no relevant changes.

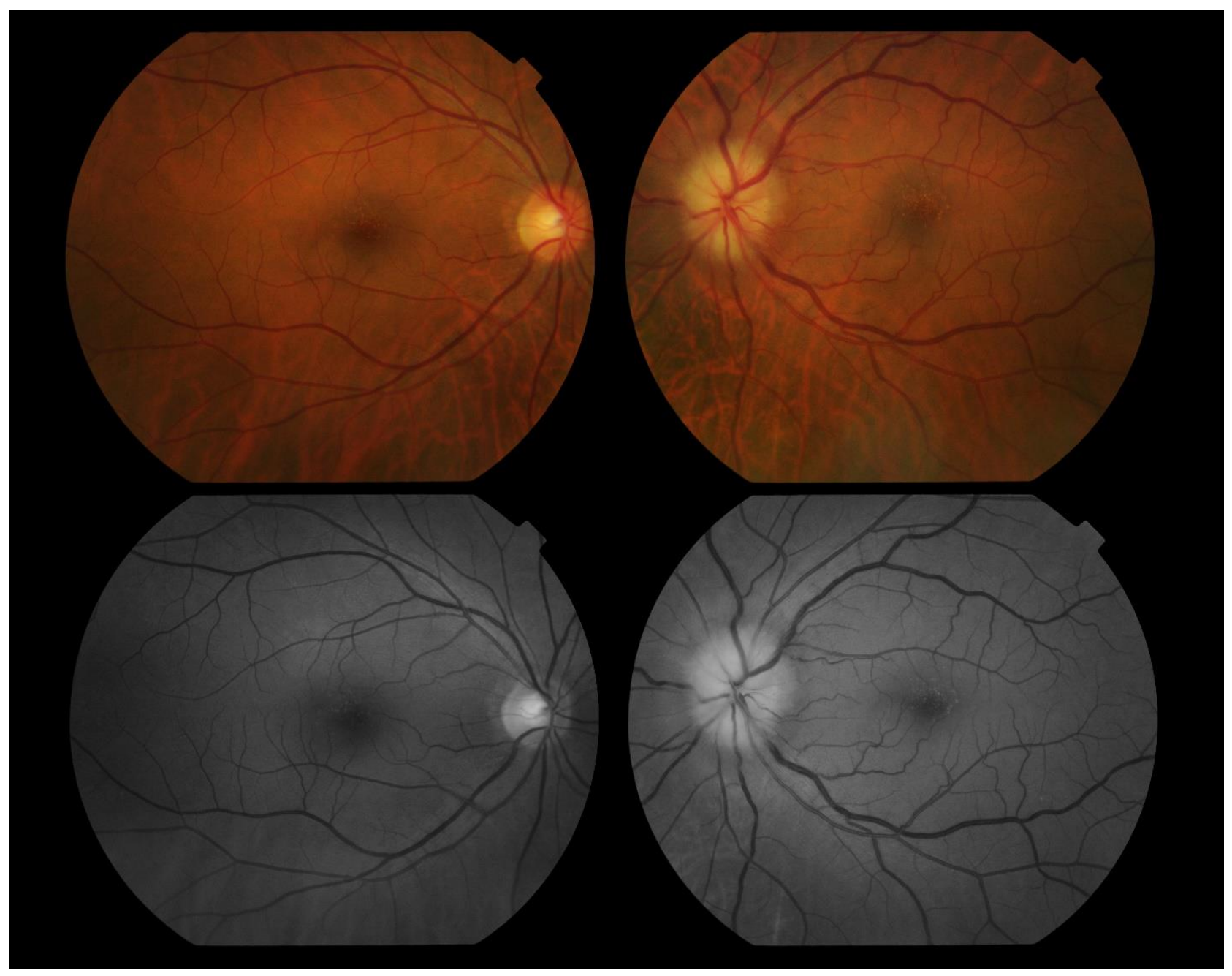

RE

LE

Fig. 1 Color and red free fundus photography of the right and left eye 

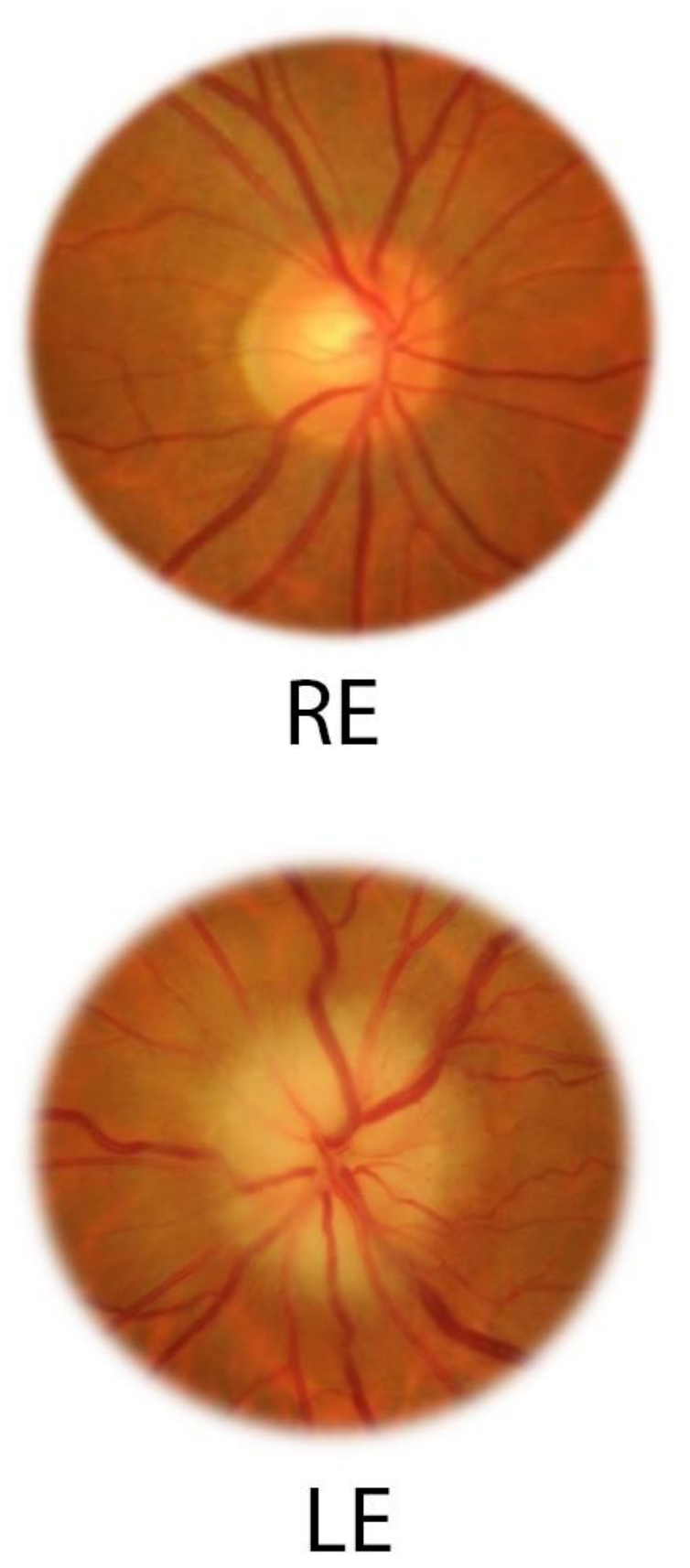

Fig. 2 Optic disc detail of the right and left eye

The ultrasonography for the left eye showed a widening (right red arrow) of the hypoechogenity representing the optic nerve sheath, which confirmed the optic nerve edema. The right eye appeared to have no pathological changes (Fig. 3).
Ultrasonography RE

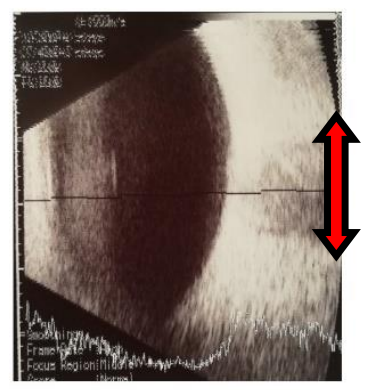

Ultrasonography LE

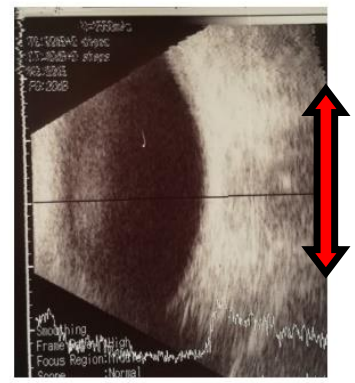

Fig. 3 Ultrasonography of the right and left eye

Perimetry was assessed by a Humphrey Visual Field Analyzer, central 24-2 threshold program, with a size III white stimulus. Reliability indices were very good in visual fields from both eyes. It demonstrated absolute scotoma in all quadrants of the left eye and it was normal for the right eye (Fig. 4).
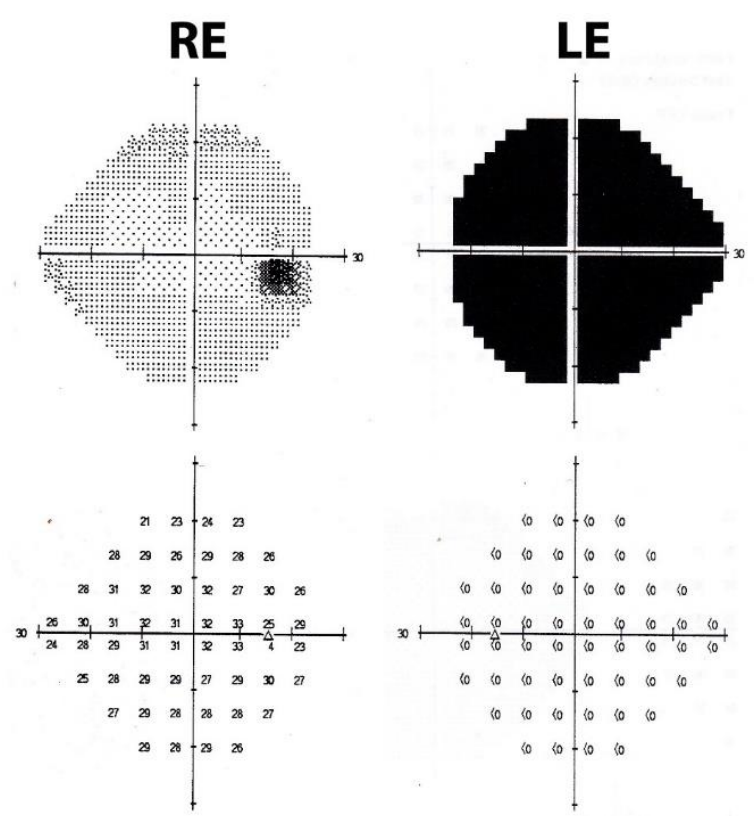

Fig. 4 Threshold values maps and grayscale maps from Humphrey visual field of both eyes

Optical coherence tomography (OCT) of the optic nerve showed a pseudo thickening of the nerve fiber layer of the left eye (Fig. 5). Both the macula and the ganglion cell layer analysis revealed no pathological changes in both eyes (Fig. 6,7). 


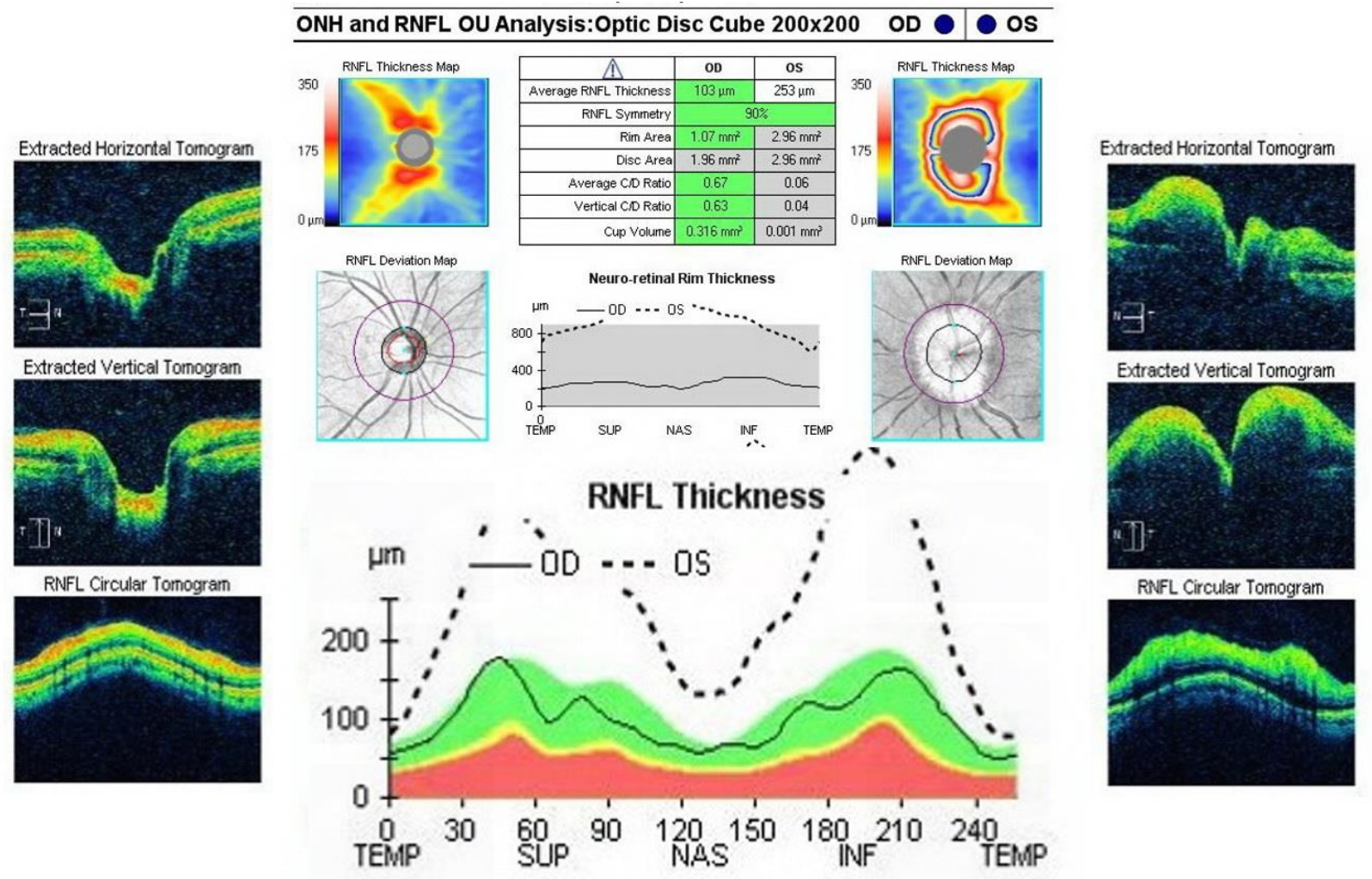

Fig. 5 Optical coherence tomography of the optic nerve in both eyes

\section{OD}

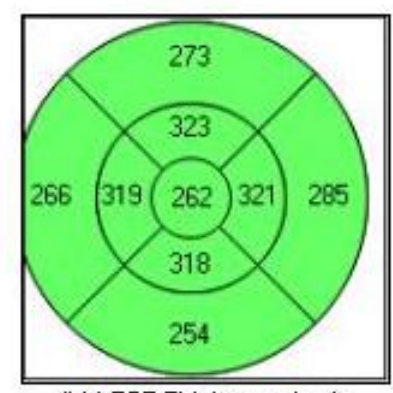

ILM-RPE Thickness ( $\mu m)$

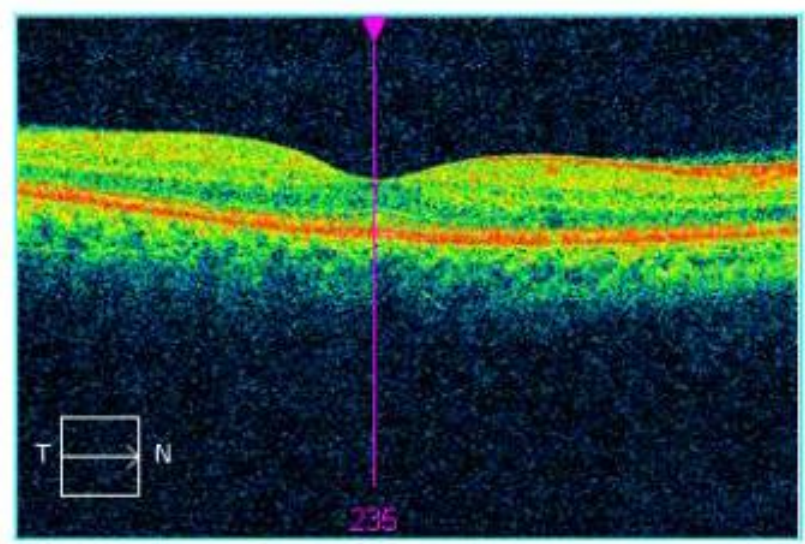

os

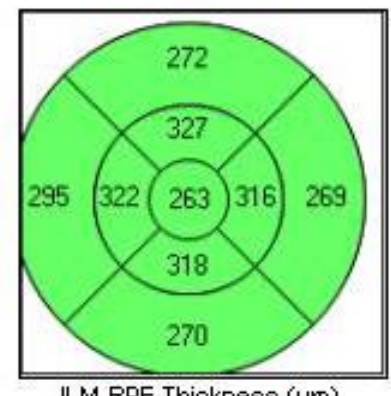

ILM-RPE Thickness ( $\mu m)$

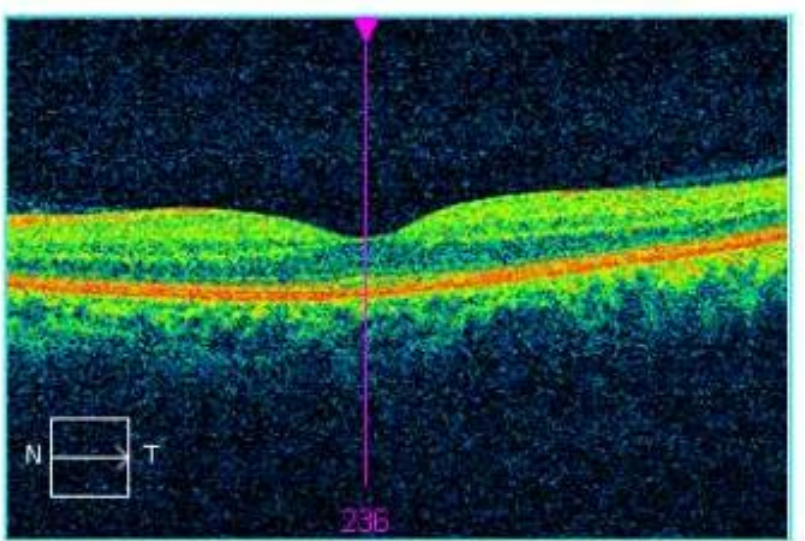

Fig. 6 Optical coherence tomography shows normal macular thickness in both eyes 

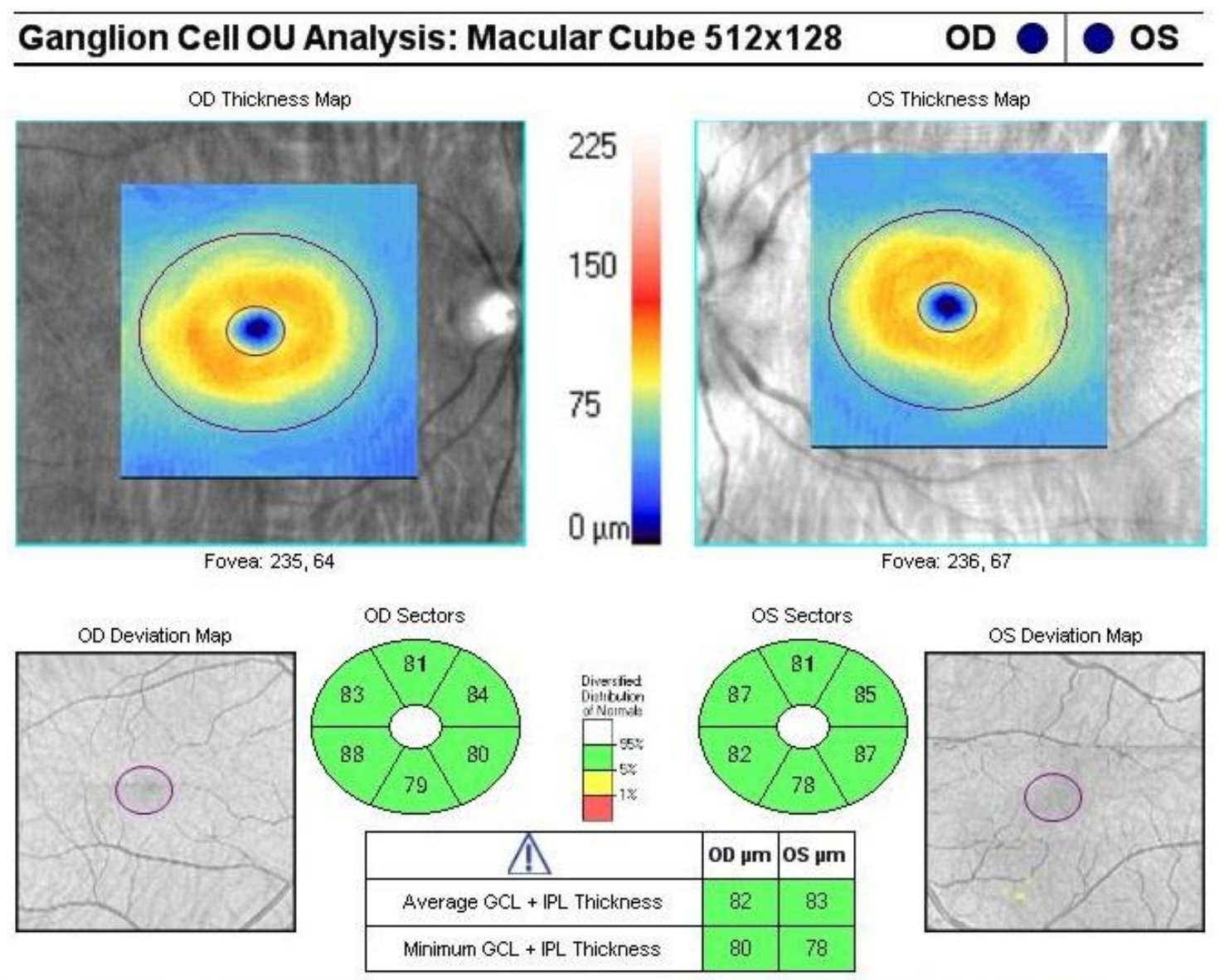

Fig. 7 Ganglion cell layer

Based on this clinical and paraclinical investigations we established the working diagnosis of Papillary Edema of the left eye. The patient was further investigated in order to establish the etiological diagnosis and the course of treatment.

We further recommended a series of clinical, paraclinical and laboratory complementary investigations. The complete blood count and erythrocyte sedimentation rate had normal values; the biochemistry showed a moderate dyslipidemia and the VDRL was negative. There were no significant findings at the neurological exam, that included a cerebral MRI, and the ENT exam showed the existence of a septum deviation irrelevant to the patient's ophthalmologic

pathology.

The endocrinological examination was within normal limits. However, the cardiologic and the dental exam revealed three possible precipitant factors: medically controlled stage II arterial hypertension, atheromatosis, and ipsilateral chronic apical periodontitis.

Considering these complementary investigations, we established the diagnosis of Non-Arteritic Anterior Ischemic Optic Neuropathy of the left eye.

The differential diagnosis included causes of papillary pseudo-edema, as well as papillary edema [10-12]. 
Table 1.

Papillary pseudo-edema

Congenital anomalies

Optic Nerve Drusen
Oblique papilla

Hypermetropic disc

\section{Exclusion factors}

The papilla had a normal orientation.

The patient had a small hyperopia of $+1,5 \mathrm{sfd}$.

The ultrasonography showed no ovoid echogenic lesion was present at the junction of the retina and the optic nerve.

Table 2.

Papillary edema

Hereditary Leber Optic Neuropathy

\begin{tabular}{ll}
$\begin{array}{l}\text { Traumatic } \\
\text { Neuropathy } \\
\text { Toxic (CO2) / metabolic } \\
\text { (uremia)/ } \\
\text { deficiency } \\
\text { Intracranial Hypertension }\end{array}$ & $\begin{array}{l}\text { Optic } \\
\text { Tumor } \\
\text { Cerebral } \\
\text { thrombosis venous } \\
\text { Idiopathic (pseudotumor } \\
\text { cerebri) } \\
\text { Meningioma } \\
\text { Thyroid Ophthalmopathy }\end{array}$ \\
\hline Compressive &
\end{tabular}

\begin{tabular}{|c|c|c|}
\hline \multirow[t]{2}{*}{ Infiltrative } & \multicolumn{2}{|l|}{ Leukemia } \\
\hline & \multicolumn{2}{|l|}{ Sarcoidosis } \\
\hline \multirow[t]{3}{*}{ Inflammatory } & \multicolumn{2}{|l|}{ Infections } \\
\hline & \multicolumn{2}{|l|}{ Sarcoidosis } \\
\hline & $\begin{array}{l}\text { Demyelinating } \\
\text { Neuritis }\end{array}$ & Optic \\
\hline Vascular & $\begin{array}{l}\text { Central Retinal } \\
\text { Occlusion } \\
\text { Malignant hyperte } \\
\text { AION }\end{array}$ & $\begin{array}{l}\text { Vein } \\
\text { ion }\end{array}$ \\
\hline
\end{tabular}

NA-AION

\section{Exclusion factors}

No family history; is usually bilateral and begins in a patient's teens or twenties.

No traumatic event in the past.

Normal laboratory results.

Normal head MRI.

Normal head MRI.

Normal neurological examination.

Normal head MRI.

No infiltration of the retro-orbital space and an endocrinological examination within normal limits.

Normal laboratory results.

No history of uveitis, no neovascularization, and chorioretinal lesions, no other systems, and organs affected.

Ipsilateral chronic apical periodontitis but with normal inflammatory tests.

No history of uveitis, no neovascularization, and chorioretinal lesions, no other systems, and organs affected.

No headache or pain on eye movement; no photopsia and a normal MRI.

No retinal hemorrhages, no macular edema or cotton wool spots.

Drug controlled arterial hypertension.

Normal inflammatory tests and absence of pain in the temporal region.
Given the above exclusion criteria and the fact that the patient presented with several elements common for NA-AION, our positive diagnosis was confirmed. The patient was male, aged between 40 and 60 , with acute, monocular, painless and non-progressive visual acuity and visual field loss, relative afferent pupillary defect and papillary edema with spontaneous remission after 8 weeks $[\mathbf{1 0 , 1 3}]$. It was commonly associated with hyperlipemia and atherosclerosis, both of them being present in this patient.

The patient was followed-up for 10 months. He received vasodilator therapy (Nicergolin $30 \mathrm{mg} /$ day), antithrombotic (Acetylsalicylic acid $75 \mathrm{mg} /$ day) and neuroprotector treatment and we recommended the treatment of the cardiologic and oral pathologies.

The right eye presented with no pathological changes during the follow-up period. 
For the left eye, the best corrected central visual acuity increased from 20/ 200 (1 logMAR) (in October 2016) to 20/20 (0 logMAR) (in December 2016). The aspect of the optic disc improved with the remission of the edema in 3 weeks, but, unfortunately, with occurrence of pallor of the disc at 2 months of follow-up (Fig. 8). The caliber of the veins also showed an improvement (black arrows).
$31 / 10 / 2016$

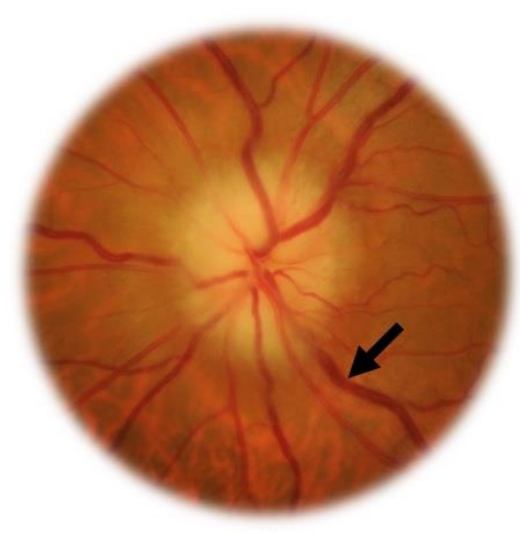

$21 / 11 / 2016$

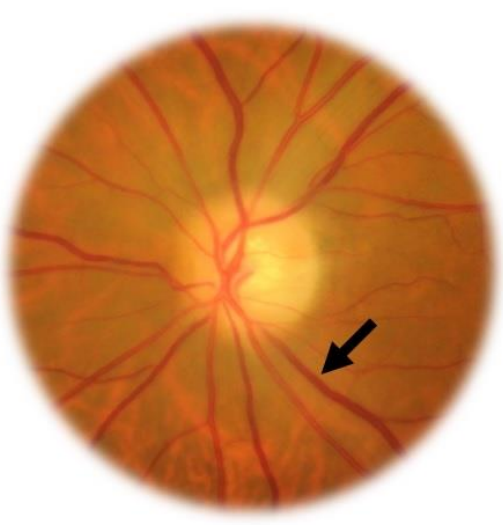

$28 / 12 / 2016$

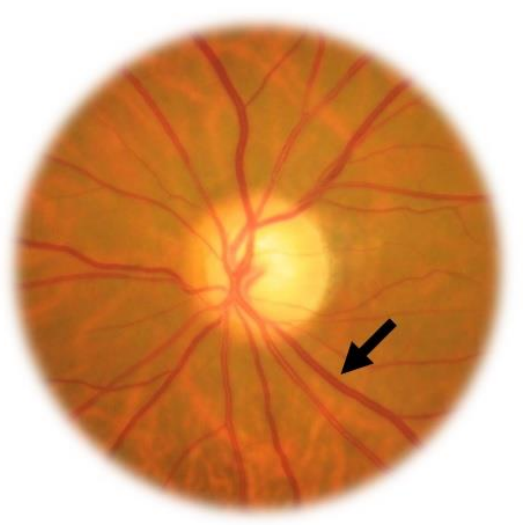

Fig. 8 Left eye - remission of the papillary edema and vein turgescence

Perimetry was assessed at every visit and during the follow-up period there was a mild improvement of the visual field, with the improvement of the central island of vision (Fig. 9).

\section{$31 / 10 / 2016$}
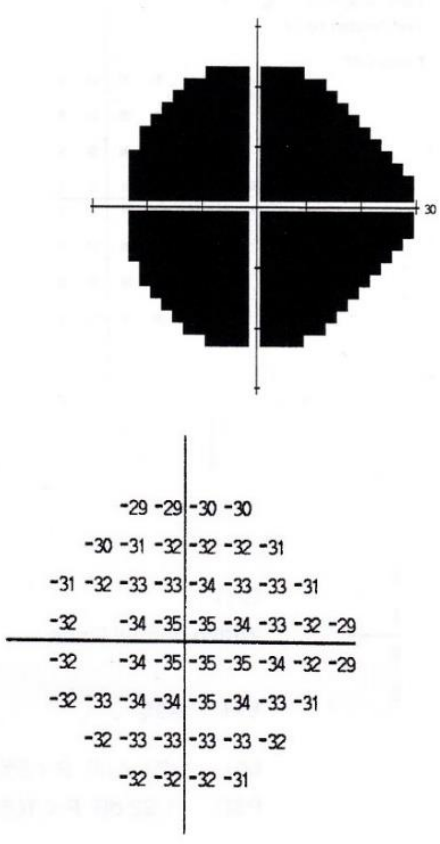

$21 / 11 / 2016$
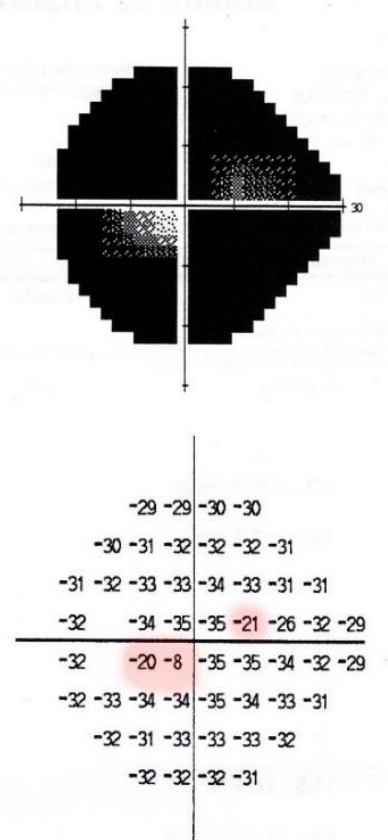

$28 / 12 / 2016$
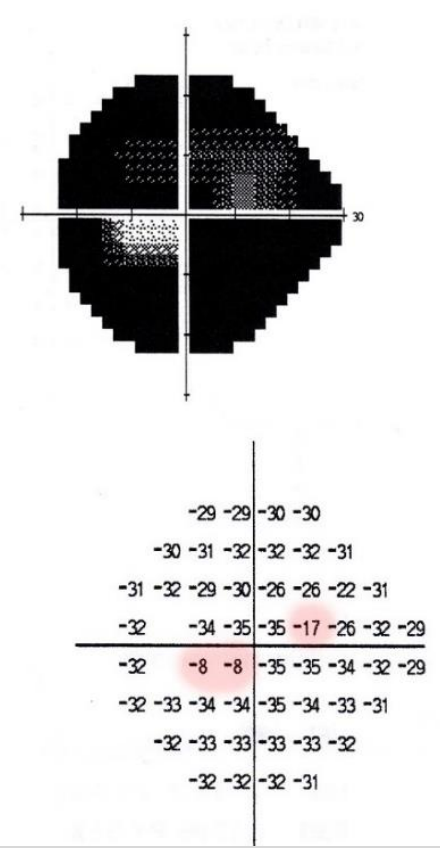

Fig. 9 Perimetry evolution in 3 months 
The evolution of the optical nerve OCT for the left eye showed an initial regression of the papillary edema at 3 weeks (Fig. 10), followed at 2 months by the thinning of the retinal nervous fiber layer. At 6 months, there was a diffuse aspect of the lesions, expanding circumferentially without affecting the nasal quadrant.

\section{$31 / 10 / 2016$}

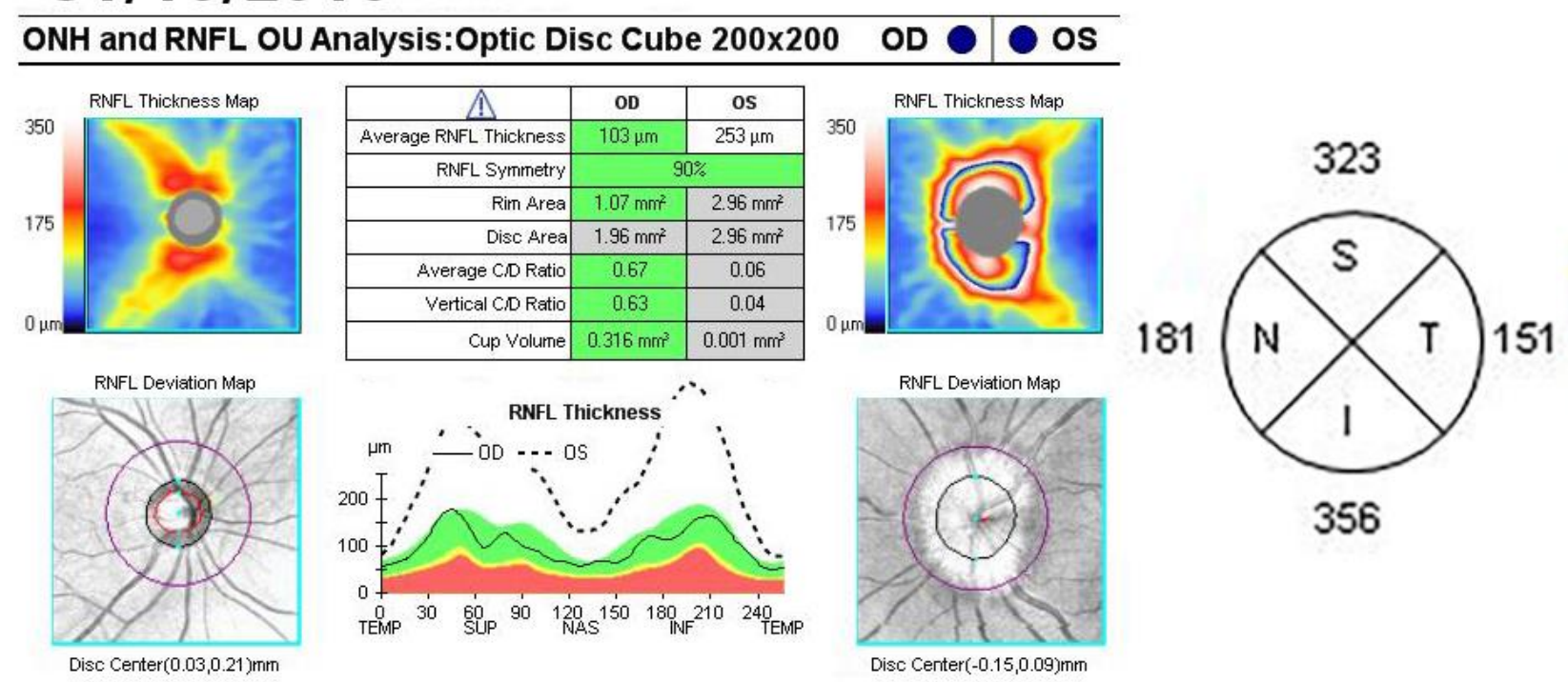

\section{$21 / 11 / 2016$}

\section{\begin{tabular}{|ll|l}
\hline ONH and RNFL OU Analysis:Optic Disc Cube 200x200 & OD & $\bullet$ OS \\
\hline
\end{tabular}}

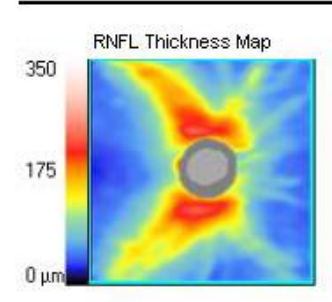

RNFL Deviation Map

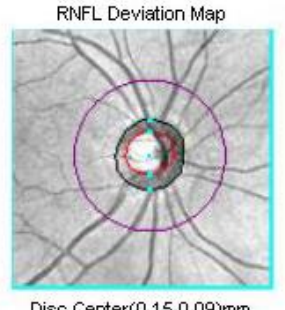

\begin{tabular}{|r|c|c|}
\hline \multicolumn{1}{|c|}{ A } & OD & OS \\
\hline Average RNFL Thickness & $104 \mu \mathrm{m}$ & $145 \mu \mathrm{m}$ \\
\hline RNFL Symmetry & \multicolumn{2}{|c|}{$88 \%$} \\
\hline Rim Area & $1.11 \mathrm{~mm}^{2}$ & $1.25 \mathrm{~mm}^{2}$ \\
\hline Disc Area & $1.99 \mathrm{~mm}^{2}$ & $2.36 \mathrm{~mm}^{2}$ \\
\hline Average CD Ratio & 0.66 & 0.67 \\
\hline Vertical CID Ratio & 0.61 & 0.66 \\
\hline Cup Volume & $0.302 \mathrm{~mm}^{3}$ & $0.307 \mathrm{~mm}^{3}$ \\
\hline
\end{tabular}

RNFL Thickness

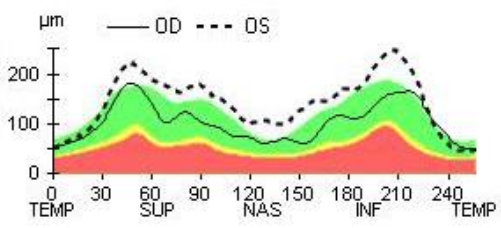

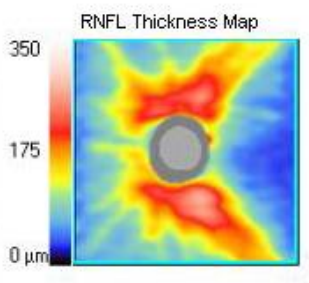

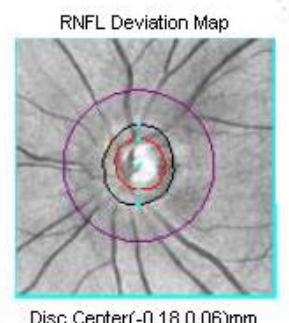

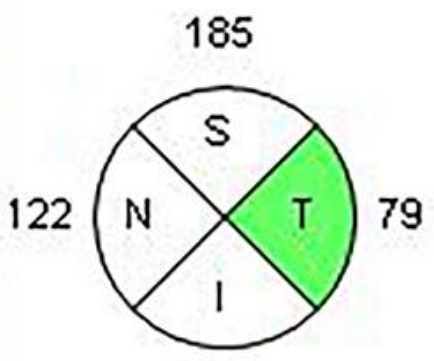

193

Fig. 10 Optic nerve OCT - the apparent average thickness of the RNFL for the left eye decreased form $253 \mu \mathrm{m}$ in October to $142 \mu \mathrm{m}$ in November 


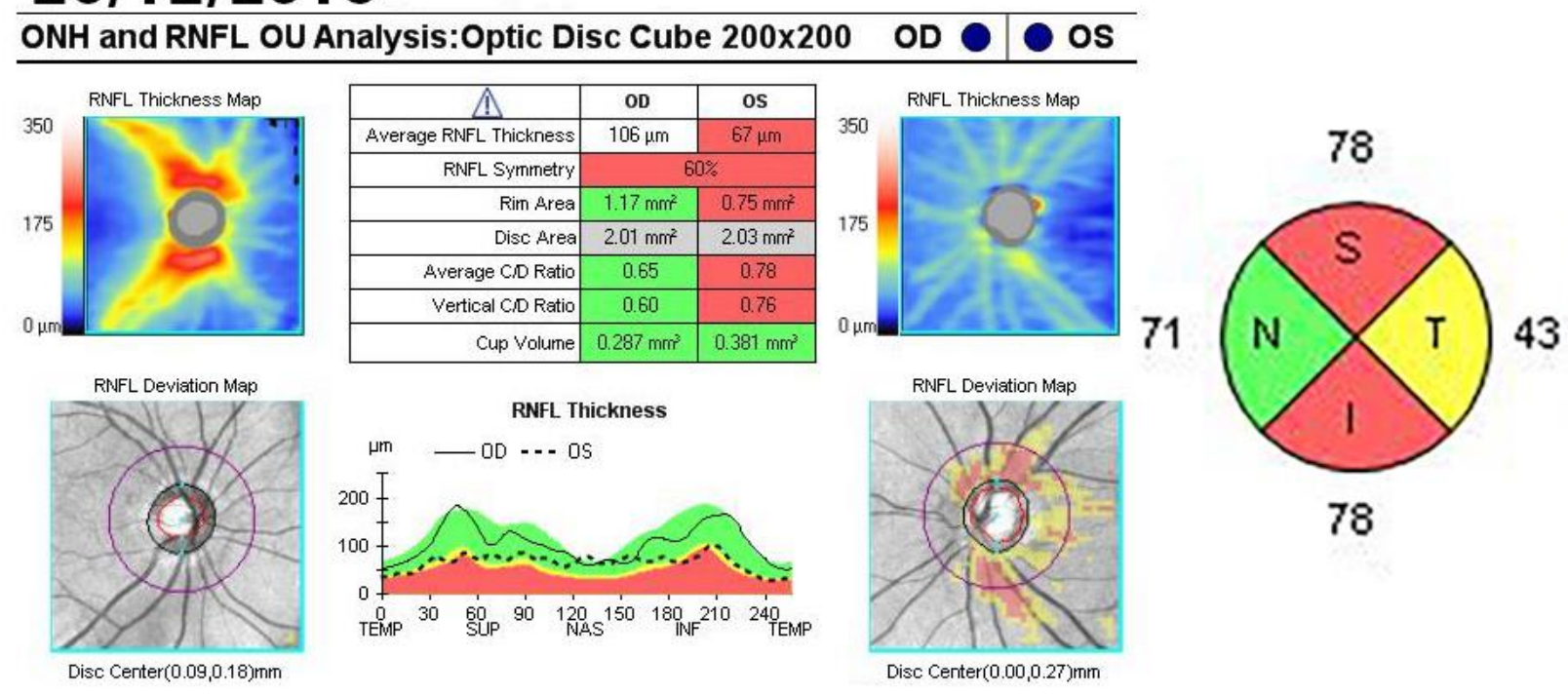

\section{$12 / 06 / 2017$}

\section{ONH and RNFL OU Analysis:Optic Disc Cube 200x200 OD $\bullet-\odot$ OS}
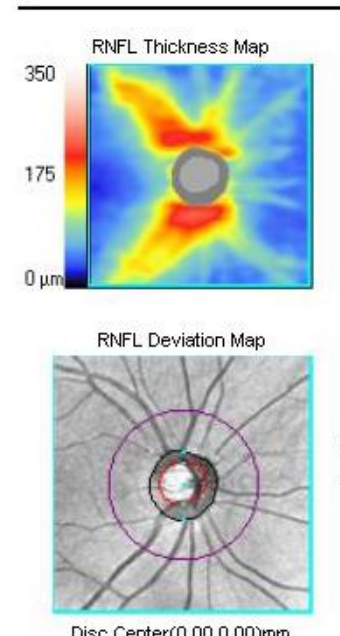

\begin{tabular}{|r|c|c|}
\hline \multicolumn{1}{|c|}{$\Lambda$ OD } & OS \\
\hline Average RNFL Thickness & $104 \mu \mathrm{m}$ & $56 \mu \mathrm{m}$ \\
\hline RNNLL Symmetry & \multicolumn{2}{|c|}{$47 \%$} \\
\hline Rim Area & $1.11 \mathrm{~mm}^{2}$ & $0.66 \mathrm{~mm}^{2}$ \\
\hline Disc Area & $1.95 \mathrm{~mm}^{2}$ & $2.06 \mathrm{~mm}^{2}$ \\
\hline Average CD Ratio & 0.65 & 0.81 \\
\hline Vertical CD Ratio & 0.61 & 0.77 \\
\hline Cup Volume & $0.289 \mathrm{~mm}^{3}$ & $0.427 \mathrm{~mm}^{3}$ \\
\hline
\end{tabular}

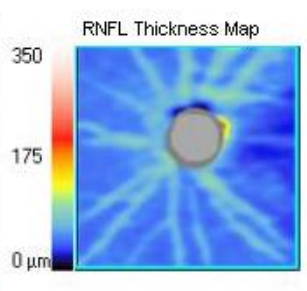

RNFL Thickness
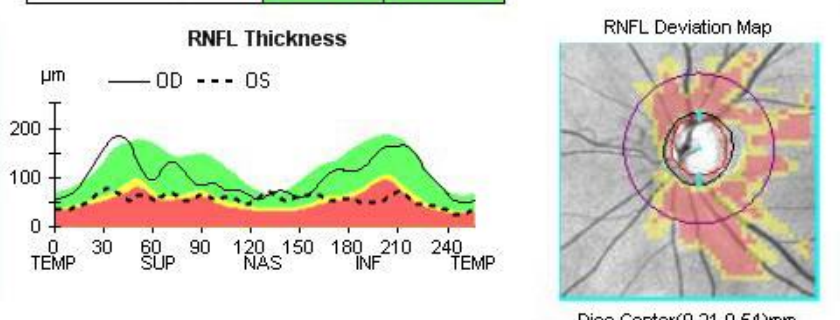

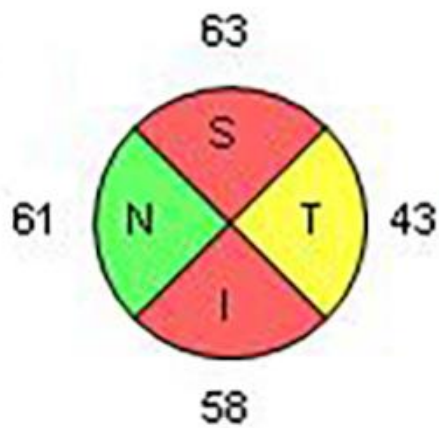

Fig. 11 Optic nerve OCT - the apparent average thickness of the RNFL for the left eye decreased even further form $67 \mu \mathrm{m}$ in December to $56 \mu \mathrm{m}$ in June

The macular thickness suffered a progressive decrease, especially in the periphery: upper quadrant from $272 \mu$ to $240 \mu$, lower quadrant from $270 \mu$ and nasal quadrant from $295 \mu$ to $250 \mu$. The central macular thickness decreased from $263 \mu$ to $252 \mu$ (Fig. 12). The macular changes occurred because of the atrophy that gradually appeared in the ganglion cell layer (Fig. 13). 

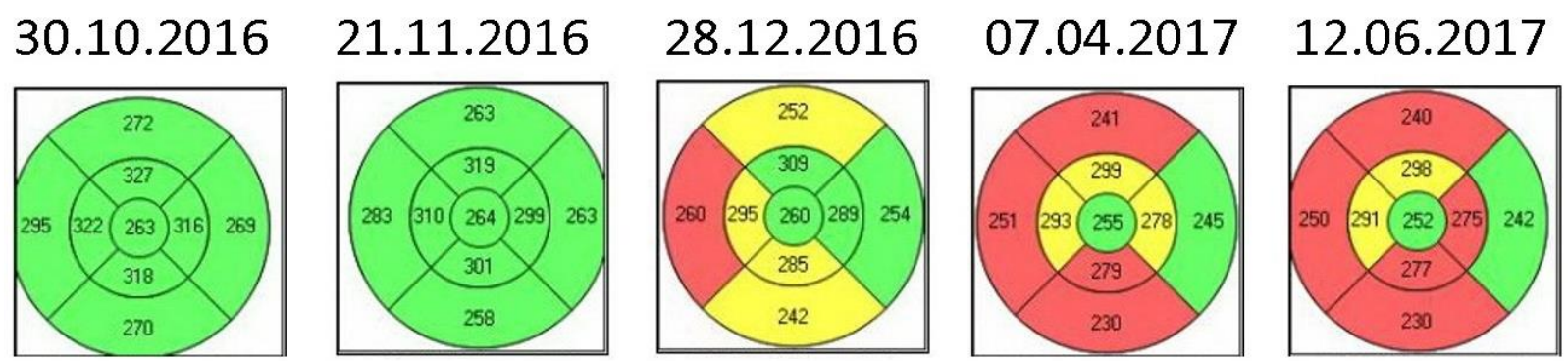

Fig. 12 Left eye - Macular OCT evolution from October 2016 to June 2017

$31 / 10 / 2016$
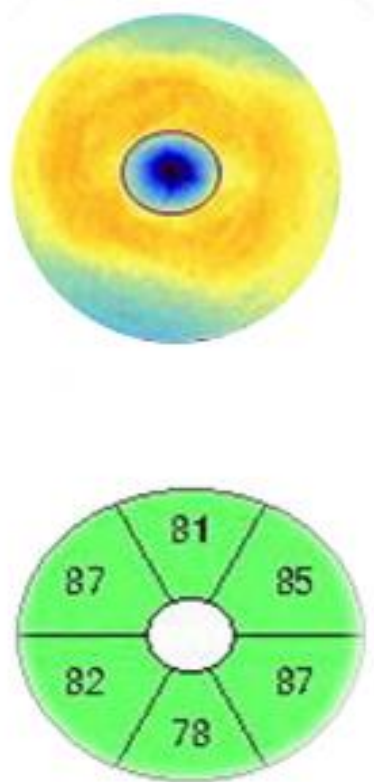

$21 / 11 / 2016 \quad 28 / 12 / 2016$
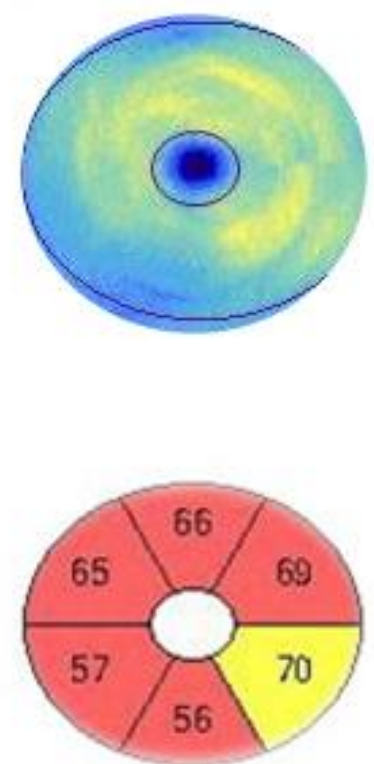
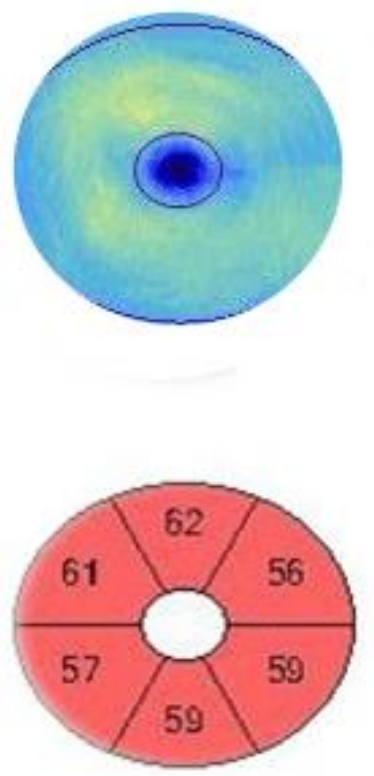

Fig. 13 Left eye - Ganglion cell layer atrophy

The best corrected central visual acuity improved progressively in 3 weeks from $20 / 200$ (1 logMAR) to $20 / 20$. The visual field had undergone minor changes with the gain of a central island of sight. The optic nerve and ganglion cell atrophy was identified by OCT at 2 months after the beginning of the disease, evolved insidiously for 6 months, and then it stabilized.

\section{Discussion}

The prognosis of this case is reserved. Optic nerve atrophy is irreversible, and currently there is no effective treatment to help nerve regeneration $[\mathbf{1 2 , 1 4}]$.

There are several theories to be discussed regarding the physiopathology of NA-AION.

Blood flow through the short posterior ciliary arteries (SPCAs) is reduced in patients with NAION [15], however, the rare cases that have been studied histopathologically have shown no evidence of thrombosis of the SPCAs $[16,17]$ and it is therefore believed that the condition is, in some cases, due to generalized hypoperfusion and in others to occlusion of disc or laminar capillaries. The lack of consistent choroidal filling delay in fluorescein angiography studies of NA-AION suggests that the impaired 
perfusion arises in the paraoptic tributaries of the SPCA's, distal to their split from the choroidal branches [18].

Persistent hypoperfusion requires impairment in the normal autoregulatory mechanisms of the optic nerve head. Flow is normally maintained constant with variations in perfusion pressure, intraocular pressure, and metabolic conditions (including tissue oxygen and $\mathrm{CO}_{2}$ levels) by factors that vary resistance to flow, such as the autonomic input. These autoregulatory mechanisms may be impaired by arteriosclerosis, chronic arterial hypertension, vasospasm, or medications, including betablockers and other antihypertensive medications [19].

Structurally small, "crowded" optic discs are associated with NA-AION [20], but the mechanism by which this contributes to ischemia has not been completely elucidated, and the role of additional factors such as nocturnal hypotension and sleep apnoea is unproven [21-27].

Almost all patients who develop NA-AION have a "disc-at-risk" [20]. The structure of the optic disc as a relatively inflexible region encompassing the axons of the optic nerve has been implicated in two histopathologic studies suggesting a compartment syndrome as a mechanism $[\mathbf{2 8 , 2 9 ]}$.

Almost all patients who develop NA-AION have at least one underlying vascular risk factor that may or may not be known at the time they lose vision. Nocturnal systemic hypotension may have a significant role in the development of NAAION, particularly in patients with an exaggerated nocturnal "dip" or in patients, such as those with systemic hypertension, in whom optic disc circulation autoregulatory mechanisms are impaired [30].

NAION has been reported in association with many conditions that may predispose to decreased optic nerve head perfusion via microvascular occlusion: systemic hypertension, diabetes mellitus [31-33], hyperlipidaemia $[34,35]$. Smoking is also a significant risk factor on the basis that smokers developed NA-AION at a significantly younger age than nonsmokers [36].

Several medications have been associated with the development of NA-AION including Interferon-alpha via systemic hypotension or immune complex deposition within the optic disc circulation. Three drugs that inhibit phosphodiesterase 5-sildenafil (Viagra), tadalafil (Cialis), and vardenafil (Levitra) may produce systemic hypotension. Amiodarone is in widespread use as a cardiac anti-arrhythmic agent and has been associated with the development of an anterior optic neuropathy that clinically mimics NA-AION [37-40].

It is not known whether ischaemia results from local arteriosclerosis with or without thrombosis, embolization from a remote source, generalized hypoperfusion, vasospasm, failure of autoregulation, or some combination of these processes.

Concerning the cellular mechanisms of the NA-AION, recent advances in the understanding of ischaemic central nervous system damage have raised new questions regarding the pathogenesis of neuronal damage in both the arteritic and nonarteritic forms of AION. Neurotrophin deprivation in retinal ganglion cells after ischaemic insult may have a significant role in cell death $[\mathbf{4 1}, \mathbf{4 2}]$. Secondary neuronal degeneration in cells adjacent to infarcted tissue may develop as a result of a toxic environment produced by the dying cells [43]. Such deterioration may be mediated by processes including excitatory amino acid (especially glutamate) toxicity, reactive oxygen species (including lipid peroxidation), intracellular calcium influx, and apoptosis $[\mathbf{1 5 , 4 4}]$. Ischaemiainduced cell death may result in release of glutamate, with further cell damage and death by excitotoxic induction of apoptosis $[\mathbf{4 4 , 4 5 ]}$. Unique animal models for optic nerve ischaemia bring fluorescein angiography based and electrophysiological evidence of early optic nerve axon damage and delayed retinal ganglion cell loss [46].

Interestingly, histological and immunohistochemical assessments, indicate a significant inflammatory reaction in the region of the ischaemic lesion, suggesting that at least some of the optic nerve damage is related to inflammation rather than ischaemia $[\mathbf{4 7 , 4 8}]$.

Several therapeutic approaches have been tried over the years and we are trying to review and comment them.

Mega-dose intravenous corticosteroid treatment was also proposed as a treatment for NA-AION [49]. The presumed mechanism 
through which corticosteroids improve the outcome in NA-AION patients is prevention of the "vicious circle" [50] in which the ischemic tissue further suffers from the secondary damage by a mechanical pressure caused by the swollen ischemic axons in an already crowded disc with a small scleral canal. This would not prevent the primary insult but should theoretically limit the secondary insult. Reducing capillary permeability in the optic disc [51] could be another mechanism.

It is feasible that if the optic nerve could be "saved" from the secondary damage caused by inflammation [52], and the mechanical damage caused by the swelling itself, a boost of IV corticosteroids (as opposed to oral treatment) would be more efficient, as was found for optic neuritis in the ONTT [53].

In the Optic Neuritis Treatment Trial three groups of patients with acute optic neuritis received: oral prednisone (1 mg per kilogram of body weight per day) for 14 days; intravenous methylprednisolone (1 g per day) for 3 days, followed by oral prednisone $(1 \mathrm{mg}$ per kilogram per day) for 11 days; or oral placebo for 14 days. Visual function was assessed over a six-month follow-up period. Intravenous methylprednisolone followed by oral prednisone speeds the recovery of visual loss due to optic neuritis and results in slightly better vision at six months. Oral prednisone alone is an ineffective treatment and increases the risk of new episodes of optic neuritis.

IV corticosteroids proved to neither improve the final VA nor the final VF of NA-AION patients compared to untreated patients, but only help reach these values faster than with no treatment at all. Of further concern is the list of systemic side effects of corticosteroids and significance of diabetes instability, hypertensive crisis, weight gain and mood instability.

Systemic oral corticosteroid administration showed some evidence of improving visual function compared to the natural evolution of acute NA-AION [54]. Other studies revealed no difference in visual outcome between treated and untreated subjects [55].

Erythropoietin has been shown to be neuroprotective in vitro and in animal models of neuronal injury [56], and can be administered intravenously, intravitreally [57], or even topically.
Hyperbaric oxygen was proven to have no beneficial effect [58].

The IONDT (Ischemic Optic Neuropathy Decompression Trial) assessed the value of optic nerve sheath fenestration (ONSF) in the treatment of acute NA-AION, based on the theory that at least some of the optic nerve damage caused by NA-AION in which there is progressive visual loss is due to post-ischaemic intraneural swelling with secondary impairment of local vascular flow or axoplasmic transport within the optic nerve head and that reduction of perineural subarachnoid cerebrospinal fluid pressure could improve vascular, axonal transport, or both, thus reducing tissue injury in reversibly damaged axons. However, data analysis revealed no significant benefit of this type of treatment $[\mathbf{5 9}, \mathbf{6 0}]$.

Transvitreal optic neurotomy has been proposed as a therapy. If a compartment syndrome is at least a component of the pathophysiology of NA-AION, in theory, such a procedure could break the cycle of edema and vascular compression [61]. However, this is a rather invasive approach.

Other studies explored the role of aspirin $[5,13,30]$, vasodilators [6], heparin-induced extracorporeal LDL/ fibrinogen precipitation (HELP) [8], hyperbaric oxygen [9], diphenylhydantoin [62], norepinephrine [63], levodopa [64], topical brimonidine [65,66] and intravitreal bevacizumab [20].

Just as there is no proven treatment for NAAION, there is no proven prophylaxis to prevent second-eye involvement. Although some authors have found evidence that aspirin can reduce the incidence of fellow-eye involvement after NAAION [67,68], others [69] found no long-term benefit for aspirin use. Nevertheless, although beneficial long-term effects remain unproven for NA-AION, many experts recommend the use of aspirin after an initial episode, only for its role in decreasing risk for stroke and myocardial infarction in this vasculopathy population group.

NA-AION has a probability of only $5 \%$ to relapse in the same eye. There is a risk of congener eye damage: $25 \%$ at 3 years, $17 \%$ at 5 years and $15 \%$ at over 5 years $[\mathbf{1 0 , 8}]$.

Particular for this case was that the patient arrived in our clinic at the onset of the symptomatology, and there was a rapid central visual acuity gain, 20/20 at 3 weeks, even 
though there is no efficient treatment demonstrated for NA-AION in the specialty literature.

The exact cause of the papillary edema has yet to be determined, with no history of hypovolemia, with a drug controlled arterial hypertension and a clinical and paraclinical examination of other systems and organs within normal limits. This causes frustration for both the doctor and the patient.

However, the physical effort and the event with emotional impact, associated with anxiety and arterial hypertension, may have contributed to a hypertensive jump that precipitated the start of NA-AION.

The burden of the treating physician is the chase "towards the end of the tunnel" for the widening of the central area of sight with limited therapeutic resources.

\section{Financial Disclosures}

None of the other authors has any financial or proprietary interests to disclose.

\section{References}

1. Hattenhauer MG, LeavittLA. Hodge DO, Grill R, Gray DT. Incidence of nonarteritic anterior ischemic optic neuropathy. Am J Ophthalmol. 1997; 123;103-107.

2. Johnson LN, Arnold AC. Incidence of nonarteritic and arteritic anterior ischemic optic neuropathy: population based study in the State of Missouri and Los Angeles County, California. J Neuroophthalmol. 1944; 14:38-44.

3. Hayreh SS. Blood supply of the optic nerve head and its role in optic atrophy, glaucoma, and oedema of the optic disc. British Journal of Ophthalmology. 1969; 53:721-748.

4. Hayreh SS. Anterior ischaemic optic neuropathy. I. Terminology and pathogenesis. British Journal of Ophthalmology. 1974; 58:955-963.

5. Ischemic Optic Neuropathy Decompression Trial Research Group. Characteristics of patients with nonarteritic anterior ischemic optic neuropathy eligible for the Ischemic Optic Neuropathy Decompression Trial. Arch Ophthalmol. 1996; 114:1366-1374.

6. Schwartz NG, Beck RW, Savino PJ, Sergott RC, Bosley TM, Lam BL et al. Pain in anterior ischemic optic neuropathy. J Neuroophthalmol. 1995; 15:9-10.

7. Repka MX, Savino PJ, Schatz NJ, Sergott RC. Clinical profile and long-term implications of anterior ischemic optic neuropathy. Am J Ophthalmol. 1983; 96:478-483.

8. Hayreh SS, Podhajsky P. Visual Field defects in anterior optic neuropathy. Doc Ophthalmol Proc Ser. 1979; 19:53-71.
9. Traustason OI, Feldon SE, Leemaster JE, Weiner JM. Anterior ischemic optic neuropathy: classification of field defects by Octopus automated static perimetry. Graefes Arch Clin Exp Ophthalmol. 1988; 226:206-212.

10. Besharse B. The Retina and its Disorders. Ischemic optic neuropathy. 2011, 399-405.

11. Moorfields J. Manual of Ophthalmology. Neuroophthalmology. Ischemic optic neuropathy. $2^{\text {nd }}$ edition, 2014, 14:670-671.

12. Besharse DD. Encyclopedia of the Eye. Ischemic Optic Neuropathy, 487-492.

13. Hayreh SS. Anterior ischaemic optic neuropathy. II. Fundus on ophthalmoscopy and fluorescein angiography. British Journal of Ophthalmology. 1974; 58:964-980.

14. Kansky's Clinical Ophthalmology, Non-arteritic anterior ischemic optic neuropathy. $8^{\text {th }}$ edition, Ch. 19, 2016, 786-787.

15. Kaup M, Plange N, Arend KO, Remky A. Retrobulbar haemodynamics in non-arteritic ischaemic optic neuorpathy. Br J Ophthalmol. 2006; 90:1350-1353.

16. Knox DL, Duke JR. Slowly progressive ischemic optic neuropathy. A clinicopathologic case report. Trans Am Acad Ophthalmol Otolaryngol. 1971; 75:1065-1068.

17. Levin LA, Louhab A. Apoptosis of retinal ganglion cells in anterior ischemic optic neuropathy. Arch Ophthalmol. 1996; 114:488-491.

18. Arnold AC, Hepler RS. Fluorescein angiography in acute nonarteritic anterior ischemic optic neuropathy. Am J Ophthalmol. 1994; 117:222-230.

19. Miller NR, Arnold AC. Current Concepts in the Diagnosis, Pathogenesis, and Management of Nonarteritic Anterior Ischaemic Optic Neuropathy. 2015; 29(1):65-79.

20. Burde RM. Optic disk risk factors for nonarteritic anterior ischemic optic neuropathy. Am J Ophthalmol. 1993; 116:759-764.

21. Mojon DS, Hedges 3rd TR, Ehrenberg B, Karam EZ, Goldblum D, Abou-Chebl A et al. Association between sleep apnea syndrome and nonarteritic anterior ischemic optic neuropathy. Arch Ophthalmol. 2002; 120:601-605.

22. Polombi K, Renard E, Levy P, Chiquet C, Deschaux Ch, Romanet JP et al. Non-arteritic anterior ischemic optic neuropathy is nearly systematically associated with obstructive sleep apnoea. Br J Ophthalmol. 2006; 90:879-882.

23. Li J, McGwin Jr G, Vaphiades MS, Owsley C. Nonarteritic anterior ischaemic optic neuropathy and presumed sleep apnoea syndrome screened by the Sleep Apnea scale of the Sleep Disorders Questionnaire (SA-SDQ). Br J Ophthalmol. 2007; 91:1524-1527.

24. Bilgin G, Koban Y, Arnold AC. Nonarteritic anterior ischemic optic neuropathy, and obstructive sleep apnea. J Neuroophthalmol. 2013; 33:232-234.

25. Stein JD, Kim DS, Mundy KM, Talwar N, Nan B, Chervin $\mathrm{RD}$ et al. The association between glaucomatous and other causes of optic neuropathy and sleep apnea. Am J Ophthalmol. 2011; 152:989-998.

26. Kolb SD, Backhouse 0. Obstructive sleep apnoea prevalence in non-arteritic anterior ischaemic optic neuropathy: a response. $\mathrm{Br} \mathrm{J}$ Ophthalmol. 2013; 97:794. 
27. Arda H, Birer S, Aksu M, Ismailogullari S, Karakucuk S, Mirza E et al. Obstructive sleep apnoea prevalence in non-arteritic anterior ischaemic optic neuropathy. Br J Ophthalmol. 2013; 97:206-209.

28. Tesser RA, Niendorf ER, Levin LA. The morphology of an infarct in nonarteritic anterior ischemic optic neuropathy. Ophthalmology. 2003; 110:2031-2035.

29. Knox DL, Kerrison JB, Green WR. Histopathologic studies of ischemic optic neuropathy. Trans Am Ophthalmol Soc. 2000; 98:203-222.

30. Hayreh SS, Podhajsky P, Zimmerman MB. Role of nocturnal arterial hypotension in optic nerve head ischemic disorders. Ophthalmologica. 1999; 213:7696.

31. Jacobson DM, Vierkant RA, Belongia EA. Nonarteritic anterior ischemic optic neuropathy. A case-control study of potential risk factors. Arch Ophthalmol. 1997; 115:1403-1407.

32. Salomon O, Huna-Baron R, Kurtz S, Steinberg DM, Moisseiev J, Rosenberg $\mathrm{N}$ et al. Analysis of prothrombotic and vascular risk factors in patients with nonarteritic anterior ischemic optic neuropathy. Ophthalmology. 1999; 106:739-742.

33. Lee MS, Grossman D, Arnold AC, Sloan FA. Incidence of nonarteritic anterior ischemic optic neuropathy: increased risk among diabetic patients. Ophthalmology. 2011; 118:959-963.

34. Talks SJ, Chong NH, Gibson JM, Dodson PM. Fibrinogen, cholesterol, and smoking as risk factors for nonarteritic anterior ischaemic optic neuropathy. Eye. 1995; 9:85-88.

35. Deramo VA, Sergott RC, Augsburger JJ, Foroozan R, Savino PJ, Leone A. Ischemic optic neuropathy as the first manifestation of elevated cholesterol levels in young patients. Ophthalmology. 2003; 110:1041-1045.

36. Chung SM, Gay CA, McCrary JA. Nonarteritic anterior ischemic optic neuropathy. The impact of tobacco use. Ophthalmology. 1994; 101:779-782.

37. Gittinger Jr JW, Asdourian GK. Papillopathy caused by amiodarone. Arch Ophthalmol. 1987; 105:349-351.

38. Feiner LA, Younge BR, Kazmier FJ, Stricker BH, Fraunfelder FT. Optic neuropathy and amiodarone therapy. Mayo Clin Proc. 1987; 62:702-717.

39. Palimar P, Cota N. Bilateral anterior ischaemic optic neuropathy following amiodarone. Eye. 1998; 12:894896.

40. Seemongal-Dass RR, Spencer SR. Bilateral optic neuropathy linked with amiodarone. Eye. 1998; 12:474-477.

41. Quigley HA, McKinnon SJ, Zack DJ, Pease ME, KerriganBaumrind LA, Kerrigan DF et al. Retrograde axonal transport of BDNF in retinal ganglion cells is blocked by acute IOP elevation in rats. Invest Ophthalmol Vis Sci. 2000; 41:3460-3466.

42. Mansour-Robaey S, Clarke DB, Wang YC, Bray GM, Aguayo AJ. Effects of ocular injury and administration of brain-derived neurotrophic factor on survival and regrowth. Proc Natl Acad Sci U S A. 1994 Mar 1; 91(5):1632-6.

43. Sucher NJ, Lipton SA, Dreyer EB. Molecular basis of glutamate toxicity in retinal ganglion cells. Vision Res. 1997; 37:3483-3493.
44. Levin LA, Clark JA, Johns LK. Effect of lipid peroxidation inhibition on retinal ganglion cell death. Invest Ophthalmol Vis Sci. 1996; 37:2744-2749.

45. Vorwerk CK, Zurakowski D, McDermott LM, Mawrin C, Dreyer EB. Effects of axonal injury on ganglion cell survival and glutamate homeostasis. Brain Res Bull. 2004; 62:485-490.

46. Chen CS, Johnson MA, Flower RA, Slater BJ, Miller NR, Bernstein SL. A primate model of nonarteritic anterior ischemic optic neuropathy. Invest Ophthalmol Vis Sci. 2008; 49:2985-2992.

47. Zhang C, Guo Y, Miller NR, Bernstein SL. Optic nerve infarction, and post-ischemic inflammation in the rodent model of anterior ischemic optic neuropathy (rAION). Brain Res. 2009; 1264:67-75.

48. Salgado C, Vilson F, Miller NR, Bernstein SL. Cellular inflammation in nonarteritic anterior ischemic optic neuropathy and its primate model. Arch Ophthalmol. 2011; 129:1583-1591.

49. Kinori M, Ben-Bassat I, Wasserzug Y, Chetrit A, HunaBaron R. Visual Outcome of Mega-dose Intravenous Corticosteroid Treatment in Non-arteritic Anterior Ischemic Optic Neuropathy - Retrospective Analysis. BMC Ophthalmol. 2014; 14(62).

50. Hayreh SS, Zimmerman MB. Non-arteritic anterior ischemic optic neuropathy: role of systemic corticosteroid therapy. Graefes Arch Clin Exp Ophthalmol. 2008; 246(7):1029-1046.

51. Foulds WS. Visual disturbances in systemic disorders. Optic neuropathy and systemic disease. Trans Ophthalmol Soc UK. 1970; 89:125-146.

52. Chen CS, Johnson MA, Flower RA, Slater BJ, Miller NR, Bernstein SL. A primate model of nonarteritic anterior ischemic optic neuropathy. Invest Ophthalmol Vis Sci. 2008; 49(7):2985-2992.

53. Beck RW, Cleary PA, Anderson MM Jr., Keltner JL, Shults WT, Kaufman DI, Buckley EG, Corbett JJ, Kupersmith MJ, Miller NR, Savino PJ, Guy JR, Trobe JD, McCrary JA, Smith CH, Chrousos GA, Thompson HS, Katz BJ, Brodsky MC, Goodwin JA, Atwell CW. The Optic Neuritis Study Group: A randomized, controlled trial of corticosteroids in the treatment of acute optic neuritis. The Optic Neuritis Study Group. N Engl J Med. 1992; 326(9):581-588.

54. Hayreh SS, Zimmerman MB. Non-arteritic anterior ischemic optic neuropathy: role of systemic corticosteroid therapy. Graefes Arch Clin Exp Ophthalmol. 2008; 246:1029-1046.

55. Rebolleda G, Pérez-López M, Casas-Llera P, MuñozNegrete FJ. Treatment of non-arteritic anterior ischemic optic neuropathy with high-dose systemic corticosteroids. Graefes Arch Clin Exp Ophthalmol. 2013 Jan; 251(1):255-60. doi: 10.1007/s00417-0121995-7.

56. Pankratova S, Kiryushko D, Sonn K, Soroka V, Køhler LB, Rathje $M$ et al. Neuroprotective properties of a novel, non-haematopoietic agonist of the erythropoietin receptor. Brain. 2010; 133:2281-2294.

57. Modarres M, Falavarjani KG, Nazari H, Sanjari MS, Aghamohammadi F, Homaii $M$ et al. Intravitreal erythropoietin injection for the treatment of nonarteritic anterior ischaemic optic neuropathy. $\mathrm{Br} \mathrm{J}$ Ophthalmol. 2011; 95:992-995. 
58. Arnold AC, Hepler RS, Lieber M, Alexander JM. Hyperbaric oxygen therapy for nonarteritic anterior ischemic optic neuropathy. Am J Ophthalmol. 1996; 122:535-541.

59. Spoor TC, Wilkinson MJ, Ramocki JM. Optic nerve sheath decompression for the treatment of progressive nonarteritic ischemic optic neuropathy. Am J Ophthalmol. 1991; 111:724-728.

60. Kelman SE, Elman MJ. Optic nerve sheath decompression for nonarteritic anterior ischemic optic neuropathy improves multiple visual function measurements. Arch Ophthalmol. 1991; 109:667-671.

61. Soheilian M, Koochek A, Yazdani S, Peyman GA. Transvitreal optic neurotomy for nonarteritic anterior ischemic optic neuropathy. Retina. 2003; 23:692-697.

62. Rader J, Feuer WJ, Anderson DR. Peripapillary vasoconstriction in the glaucomas and the anterior ischemic optic neuropathies. Am J Ophthalmol. 1994; 117:72-80.

63. Jonas JB, Gusek GC, Naumann GO. Anterior ischemic optic neuropathy: nonarteritic form in small and giant cell arteritis in normal-sized optic discs. Int Ophthalmol. 1988; 12:119-125.

64. Mansour AM, Shoch D, Logani S. Optic disk size in ischemic optic neuropathy. Am J Ophthalmol. 1988; 106:587-589.

65. Beck RW, Savino PJ, Repka MX, Schatz NJ, Sergott RC. Optic disc structure in anterior ischemic optic neuropathy. Ophthalmology. 1984; 91:1334-1337.

66. Beck RW, Servais GE, Hayreh SS. Anterior ischemic optic neuropathy. IX. Cup-to-disc ratio and its role in pathogenesis. Ophthalmology. 1987; 94:1503-1508.

67. Kupersmith MJ, Frohman L, Sanderson M, Jacobs J, Hirschfeld J, Ku C et al. Aspirin reduces the incidence of second eye NAION: a retrospective study. J Neuroophthalmol. 1997; 17:250-253.

68. Salomon O, Huna-Baron R, Steinberg DM, Kurtz S, Seligsohn U. Role of aspirin in reducing the frequency of second eye involvement in patients with nonarteritic anterior ischaemic optic neuropathy. Eye. 1999; 13:357-359.

69. Beck RW, Hayreh SS. Role of aspirin in reducing the frequency of second eye involvement in patients with non-arteritic anterior ischaemic optic neuropathy. Eye. 2000; $14: 118$. 